\title{
Opettajankouluttajat ristiriitaisten vaateiden keskellä: yksilön ja organisaation välisiä jännitteitä
}

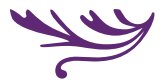 \\ Opettajankouluttajien oman ammatillisen kehittymisen ja \\ opettajankoulutuslaitoksen kehittymisen välillä vallitsee ristiriita. Aineryhmien \\ olematon yhteistyö vaikuttaa opettajankoulutuksen toteuttamiseen ja \\ heijastuu vahvasti myös opiskelijoihin. Opettajankouluttajat kuvaavat omaa \\ organisaatiotaan vanhoihin tapoihinsa kangistuneeksi ja hitaasti kehittyväksi. \\ Muutosta jarruttaa sisäinen kilpailu.
}

SUOMALAISELLA KOULULLA ja opettajankoulutuksella menee lujaa! Kiitosta satelee ympäri maailmaa alan arvostetuimpien tutkijoiden ja koulutuksen kehittäjien sekä johtavien poliitikkojen suunnalta. Maatamme on tituleerattu kasvatuksen- ja koulutuksen mallimaana, Pisa-ihmeenä ja jopa koko maailman koulutuksen suunnannäyttäjänä. Voimme syystä olla ylpeitä suomalaisen koulun, koulujärjestelmän ja opettajankoulutuksen hyvästä laadusta.

Nykyinen menestyksemme ei ole sattumaa, vaan tavoitteellisen ja pitkäjänteisen koulutuspolitiikan ansiota. Nykyisestä menestyksestämme meidän on pitkälti kiittäminen 1960-70 luvun kasvatusalan toimijoita ja päätöksentekijöitä, jotka loivat maahamme yhtenäisen peruskoulutuksen ja sitä tukemaan yliopistotasoisen opettajankoulutuksen. Vuonna 1971 annettu laki opettajankoulutuksesta määritteli koko yleissivistävän koulun opettajankoulutuksen siirrettäväksi yliopistoihin. Seuraava tärkeä etappi oli vuosi 1979, jolloin opettajankoulutus, niin perus- kuin aineenopettaja- koulutus määriteltiin maisteritasoiseksi koulutukseksi. Maamme yleissivistävän koulun opettajankoulutus on siis ollut akateemista ja maisteritasoista jo yli 30 vuotta. Tämä on kansainvälisesti ainutlaatuista. Yleisin malli muualla on se, että luokanopettajan tutkinto on alempi korkeakoulututkinto eli kandidaatin tutkinto ja aineenopettajantutkinto ylempi maisterin tutkinto.

Suomalainen opettajankoulutus onkin monin tavoin kansainvälisesti poikkeuksellinen järjestelmä. Sen lisäksi että opettajankoulutuksemme on akateemista ja maisteritasoista se on myös laadultaan korkeatasoista. Opettajankoulutustutkinto pitää sisällään tutkimusmenetelmänopintoja sekä pro-gradu työn. Näin ollen kaikki luokanopettajiksi valmistuvat saavat tutkijankoulutuksen ja myös jatko-opintokelpoisuuden tohtoriopintoihin.

Opettajan työn arvostus on maassamme korkeaa. Tämä on taannut sen, että opettajankoulutukseen hakeutuu lahjakkaita hakijoita ja opettajankoulutukseen voidaan valita alalle hyvin soveltuvia ja akatee- 
misilta taidoiltaan lähtökohtaisesti vahvoja opiskelijoita. Tämä on myös kansainvälisesti hyvin poikkeava tilanne. Useissa maissa opettajankoulutukseen ei ole riittävästi hakijoita ja esimerkiksi Euroopassa opettajista tulee olemaan lähivuosina huutava pula.

Meillä ei myöskään opettajankouluttajien eikä opettajien työtä arvioida ja mitata ulkopuolisilla tulosmittareilla, eikä meillä ole hallinnollista arviointija tarkastusjärjestelmää. Koulutuksen laatu ja sen kehittäminen perustuu opettajien asiantuntemukseen ja oman työnsä kehittämiseen. Kansainvälisillä kentillä ihmetellään jatkuvasti, kuinka Suomi voi olla niin tehokas ja tuottaa niin hyviä oppimistuloksia ilman ulkopuolista arviointijärjestelmää.

\section{MIKSI TUTKIA OPETTAJANKOULUTUSTA?}

Kun nyt saamme nauttia kunniasta ja menestyksestä, niin voi hyvällä syyllä kysyä, onko mitään tarvetta tutkia opettajankoulutusta, kun kerran todistettavasti osaamme sen jo niin hyvin?

Toisaalta, monet tutkimukset niin meillä kuin muuallakin ovat todenneet, että opettajankoulutusta on vaikea muuttaa ja että muutokset ovat hitaita ja vaikutuksiltaan heikkoja. Samalla kun yhteiskunnat ja maailma muuttuvat yhä kasvavaa vauhtia, on aiheellista kysyä, kuinka opettajankoulutus pystyy tähän muutokseen vastaamaan. Yhteiskunnallisina haasteina on viimeaikoina noussut voimakkaasti esiin esimerkiksi nuorten syrjäytyminen, lisääntyvä suvaitsemattomuus, opettajien työuupumus, kansainvälistymisen paineet, yhteiskunnan teknologisoituminen ja yrittäjämäisyyden omaksuminen. Samalla on noussut keskusteluun, kuka koulun ja opettajankoulutuksen muutoksesta vastaa ja kuka sitä ohjaa: poliittiset päätöksen tekijät, elinkeinoelämä, globaali markkinatalous vaiko kenties opettajat itse?

Lisäksi opettajankoulutuksesta ja erityisesti opettajankouluttajista tiedetään melko vähän. Kansainvälisesti on todettu, että kasvatustieteen tutkimuksessa perusasteen opettajankoulutus on yksi vähiten tutkituista alueista. Suomessa opettajankoulutusta on tutkittu jonkin verran. Tutkimus on keskittynyt pääasiassa opettajankoulutuksen rakenteiden tarkasteluun, opettajankoulutustarpeen märittelyyn, pedagogiseen tietoon tai opetussuunnitelmaan liit- tyviin tekijöihin. Kuten kansainvälisestä, myös suomalaisesta opettajankoulutustutkimuksesta puuttuu opettajankouluttajien tutkimus, heidän ammatillisen oppimisensa ja identiteettinsä tarkastelu sekä yksilön ja yhteisön välisten yhteyksien tutkimus.

Pyrin tutkimukseni syventämään ymmärrystä opettajankoulutuksen kehittämisestä ja erityisesti niistä haasteista ja esteistä, joita koulutuksen uudistamiseen liittyy. Päätavoitteena oli löytää uusia näkökulmia siihen, miksi opettajankoulutuksen vakiintuneiden käytäntöjen, opetuksen ja toiminnan rakenteiden muuttaminen vaikuttaa olevan vaikeaa kaikkialla maailmassa. Pyrin tähän tarkastelemalla opettajankouluttajien ammatillisen kehittymisen ja organisaation kehittymisen välistä suhdetta.

Tutkimuskysymykset olivat seuraavat: 1. Minkälaisia mahdollisuuksia ja esteitä opettajankoulutuslaitos tarjosi opettajankouluttajien ammatilliseen kehittymiseen?

2. Kuinka opettajankouluttajat harjoittivat toimijuutta työyhteisössään, ja kuinka tämä oli yhteydessä heidän ammatillisen identiteettinsä neuvotteluihin? 3. Minkälaista oli opettajankoulutuslaitoksen yhteisöllinen ja organisaation kehittyminen?

\section{SOSIOKULTTUURINEN LÄHESTYMISTAPA}

Tutkimuksen teoreettiset lähtökohdat ovat sosiokulttuurisessa teoriassa. Tämä lähestymistapa ei ole kiinnostunut siitä, mitä ihmisen pään sisässä tapahtuu - miten ihminen esimerkiksi hahmottaa asioita tai muistaa niitä. Sosiokulttuurisessa lähestymistavassa lähtökohtana on ajatus siitä, että oppiminen on aina ensisijaisesti sosiaalinen ilmiö, joka tapahtuu ihmisten välisessä vuorovaikutuksessa yksilöiden osallistuessa erilaisten yhteisöjen toimintaan. Tällöin kehittymisen tarkastelu kiinnittyy erityisesti ihmisten väliseen toimintaan ja vuorovaikutukseen, puheeseen, yhteisöissä vallitseviin diskursseihin, jaettuihin käytänteisiin ja merkityksenantoihin. Oppimisessa ja kehittymisessä nähdään tärkeimpänä se, minkälaisiin sosiaalisiin yhteisöihin yksilö kuuluu ja kuinka hän pystyy näissä yhteisöissä toimimaan. Osallisuuden ja osallistumisen käsitteet ovat tällöin keskeisiä.

Tarkastelin sosiokulttuurisesta lähestymistavasta opettajankouluttajien ammatillista kehittymistä pää- 
sääntöisesti heidän mahdollisuuksinaan osallistua eri käytäntöyhteisöjen toimintaan ja ammatillisen identiteetin uudelleenneuvotteluihin. Organisaation kehittymisen ymmärsin organisaation kykynä tukea työntekijöiden ammatillista kehittymistä, yhteisöllistä toimintaa ja eri käytäntöyhteisöjen yhteistyötä sekä uudistaa toimintakäytänteitä.

Sosiokulttuurisen lähestymistavan viitekehyksessä pääkäsitteinä hyödynsin ammatillisen identiteetin ja ammatillisen toimijuuden käsitteitä. Ammatillisen identiteetin ymmärsin niinä tekijöinä, joihin opettajankouluttaja vahvimmin työssään identifioituu ja minkälaisena ammatillisena toimijana hän itsensä näkee. Oleellisia ovat tällöin ne orientaatiot ja arvot, jotka ovat tärkeimpiä kouluttajille sekä se, mihin he vahvimmin työssään sitoutuvat.

Toimijuuden määrittelin opettajankouluttajien mahdollisuudeksi osallistua yhteisönsä toimintaan sekä vaikuttaa omaan työhönsä, työyhteisöönsä ja sitä koskevaan päätöksentekoon. Lisäksi määrittelin toimijuuden mahdollisuutena ammatillisen identiteetin uudelleenneuvotteluun.

\section{METODINA AVOIMET HAASTATTELUT}

Tutkimuksen pääaineisto koostuu kahdeksasta avoimesta opettajankouluttajahaastattelusta, jotka toteutin lukuvuoden 2005 aikana työskennellessäni tutkimassani opettajankoulutuslaitoksessa. Haastateltavat opettajankouluttajat oli valittu tutkimukseen harkinnanvaraisesti siten, että he kukin olivat avainhenkilöitä eri kriteereillä määriteltynä. Halusin aineistoon mahdollisimman kattavasti erilaisia opettajankouluttajia ja kriteereinä käytin opettajankouluttajien opetettavaa ainetta, ikää, sukupuolta, ammatillista statusta ja työnimekettä, sekä työvuosia kyseisessä opettajankoulutuslaitoksessa. Haastattelu oli luonteeltaan keskusteluomainen mutta keskustelua ohjasi etukäteen laadittu haastattelurunko.

Lisäksi hyödynsin tutkimuksessa tutkimuspäiväkirjaa, jota pidin vuosina 2002-2006. Olin merkinnyt päiväkirjaan erilaisia tapahtumia kuten laitoksen kokouksia, kehittämispäiviä ja erilaisia työryhmiä sekä omia kokemuksiani ja havaintojani niistä.

Analysoin aineiston käyttämällä laadullista sisällönanalyysia, temaattista analyysiä sekä diskursiivista analyysiä. Näissä analyyseissä en pyrkinyt kartoittamaan opettajankouluttajien yksittäisten kokemusten tai merkitysten kirjoa, vaan keskityin sosiaalisesti jaettujen ja yhteisten merkitysten löytämiseen.

\section{KEHITTYMISESSÄ JÄNNITTEINEN SUHDE}

Tutkimus osoitti, että opettajankoulutuslaitos tarjosi erinomaiset mahdollisuudet ja runsaasti resursseja opettajankouluttajien ammatilliseen kehittymiseen. Opettajankouluttajat kuvasivat, että työ opettajankouluttajana oli hyvin vapaata ja se tarjosi mahdollisuuksia jatkuvaan oman työn kehittämiseen ja ammatilliseen kasvuun. Opettajankouluttajat kertoivat, että heidän ammatillinen kasvunsa oli läheisesti sidoksissa oman työn suunnitteluun ja toteuttamiseen ja että siihen heillä oli lähes rajattomat mahdollisuudet. Eräs opettajankouluttaja kuvasi asiaa näin: "Yks tän talon parhaita puolia on se, ettei ole rajoja oman työn kehittämiselle." Mahdollisuus oman työn vapaaseen toteuttamiseen ja kehittämiseen vahvisti kouluttajien sitoutumista työhön ja organisaatioon. Opettajankouluttajat toivoivat voivansa jatkaa työtään myös tulevaisuudessa laitoksessa.

Tutkimus paljasti, että opettajankouluttajien oman ammatillisen kehittymisen ja organisaation kehittymisen välillä vallitsi ristiriita. Opettajankoulutuslaitoksen yhteisöllinen ja organisaation kehittyminen kuvattiin haasteelliseksi. Opettajankoulutuslaitoksen organisaation yhteisöllisen kehittymisen esteenä korostuivat aineryhmien välinen olematon yhteistyö ja selvät raja-aidat eri ryhmien välillä. Vähäisen yhteistyön nähtiin vaikuttavan myös opettajankoulutuksen toteuttamiseen, jolloin sen vaikutukset heijastuivat vahvasti myös opiskelijoihin. Oma organisaatio kuvattiin vanhoihin tapoihinsa kangistuneeksi ja hitaasti kehittyväksi. Eräs opettajankouluttaja kuvasi tilannetta näin: "Kyl sellanen kauhuskenaarion on olemassa, et juna jatkaa kulkuaan entiseen malliin ... että kuoret muuttuu mutta toteutukset ja sisällöt ei. Se muutos on niin pientä ja hidasta että siinä ehtii mennä liian monta opiskelija sukupolvea läpi."

Tutkimuksessa tuli ilmi, että opettajankouluttajien vahva yksiöllinen mahdollisuus vaikuttaa omaan työhönsä tuki heidän ammatillista oppimistaan, mutta esti samalla yhteisön ja organisaation kehittymistä. 


\section{AMMATILLISEN IDENTITEETIN UUDISTAMINEN VAIKEAA}

Opettajankouluttajien työ on erittäin haasteellista ja vaativaa. Työn vaativuus on lisääntynyt viimeaikaisten yliopistosektoria koskevien tehokkuusvaatimusten sekä yhteiskunnallisten muutosten myötä. Nämä muutoksesekä opettajankouluttajien ammattiin liittyvä elinikäisen kehittymisen vaade haastavat opettajankouluttajat jatkuvaan ammatillisen identiteetin muutokseen.

Tulokset osoittivat, että opettajankouluttajien ammatillinen identiteetti kiinnittyi vahvasti omaan opettajuuteen ja opetettavaan oppiaineeseen. Ammatillinen toimijuus ilmeni erityisesti yksilöllisenä vahvana toimintana ja vaikuttamisena oman opetuksen kehittämiseen ja oman oppiaineen opetusresurssien turvaamiseen.

Ammatillisen identiteetin uudistamiseen liittyi kuitenkin myös huomattavia rajoitteita. Opettajankouluttajien ammatillisen identiteetin uudistamisen vaikeus näyttäytyi erityisesti laitoksen sisäisinä ja kollektiivisesti tuotettuina muuttumattomina ja vakiintuneina positioina. Opettajankouluttajien toimijuus oli rajattua uusien identiteettipositioiden neuvottelussa omassa työyhteisössä organisaation sisällä. Tämä tarkoittaa esimerkiksi sitä, että opettajankouluttajat eivät pystyneet jakamaan ja tuomaan esiin kaikkea osaamistaan ja asiantuntijuuttaan organisaation sisällä.

Lisäksi tutkijaidentiteetin neuvottelu näyttäytyi vaikeana. Resurssit ja tilat tutkijaidentiteetin rakentamiseen olivat niukat. Esimerkiksi oppiaineiden aineryhmät, jotka näyttäytyivät keskeisenä resurssina opettajaidentiteetin neuvottelussa, eivät toimineet lainkaan resurssina tutkijaidentiteetin neuvottelussa tai tutkijana toimimisessa. Tutkijana toimiminen kuvattiin haastatteluissa pääasiassa vapaa-ajan harrastuksena, johon käytettiin ilta-aikaa ja lomia. Toisin sanoen tutkimus ei ollut oleellinen osa opettajankouluttajien arjen työtä, vaan siihen piti käyttää lepoon ja vapaa-aikaan tarkoitettua aikaa.

\section{KILPAILUN KULTTUURI ESTÄÄ YHTEISTYÖTÄ JA KEHITYSTÄ}

Keskeisenä opettajankoulutuksen kehittämisen haasteena ilmeni työyhteisössä vallitseva sisäinen kilpailu resursseista. Vallitseva puhetapa kuvattaessa opetta- jankoulutusta oli kilpailudiskurssi, jonka mukaan eri oppiaineet ja niiden opettajat käyvät jatkuvaa resurssikamppailua rajallisista resursseista kuten opetussuunnitelman opintopisteistä, kontaktiopetustunneista ja tuntiopetusresursseista sekä oppiaineen arvostuksesta. Erityisesti tämä diskurssi ilmeni puhuttaessa peruskoulussa opetettavista monialaisista opinnoista.

Kilpailudiskurssi ilmeni haastatteluissa itsestäänselvyytenä, jota ei tarvinnut erikseen perustella tai määritellä, vaan opettajankoulutuksesta puhuminen kilpailurepertuaariin tukeutuen näyttäytyi sosiaalisesti jaettuna yhteisenä resurssina ja tapana ymmärtää opettajankoulutuksen todellisuutta. Tämän kamppailun tavoitteena on turvata oman oppiaineen ja samalla oman työn edellytykset. Puhetapa määritteli opettajankouluttajat keskinäisiksi kilpailijoiksi ja oman oppiaineensa lobbaajiksi. Kilpailun kulttuuri loi monia esteitä opettajankouluttajien keskinäiselle yhteistyölle ja sitä kautta yhteisön ja organisaation kehittymiselle.

Muita opettajankoulutusta kuvaavia repertuaareja olivat aineenopetus-, yhteistyö-, tutkimus- ja tradition murtamisrepertuaari. Nämä eri puhetavat voitiin jaotella kahteen eri pääluokkaan: sopeuttavaan ja uudistavaan repertuaariin. Sopeuttavan puhetavan tunnuspiirteenä oli näkemys opettajankoulutuksen säilyttämisestä entisellään ja sen maltillisesta kehittämisestä peruskoulun opetussuunnitelman muutoksia seuraillen. Uudistava repertuaari sitä vastoin kuvasi opettajankoulutuksen tavoitteeksi kasvatustodellisuuden muuttamisen ja määritteli opettajankoulutuksen opetussuunnitelman suunnannäyttäjäksi laajemminkin kasvatustieteellisen tiedon ja opetuksen kehittämisessä.

Tutkimuksen tulosten perusteella esitä, että seuraavat neljä tekijää kuvaavat opettajankouluttajien ammatillisen kehittymisen sekä opettajankoulutuksen kehittämisen välisiä jännitteitä:

- opettajankouluttajien ammatillisen identiteetin uudistumista estävät kulttuuriset ja rakenteelliset tekijät

- rajanylitysten vähäisyys opettajankoulutuslaitoksen sisällä ja erityisesti eri aineryhmien välillä

- resurssikamppailut eri aineryhmien välillä

- ristiriita opettajankouluttajien vahvan yksilöllisen toimijuuden ja organisaation kehittämisen välillä. 
Nämä tekijät voidaan nähdä myös opettajankoulutuksen kehittämishaasteina, joihin olisi tarpeellista kiinnittää huomiota pyrittäessä vastaamaan opettajankoulutukseen kohdistuviin moninaisiin vaateisiin.

\section{JOHTOPÄÄTÖKSIÄ JA POHDINTAA}

Teoreettisina johtopäätöksinä tutkimukseni nosti esiin diskurssien merkityksen organisaatioiden kehittämisessä ja erityisesti kehittymisen esteiden ymmärtämisessä. Organisaatiossa vallitsevia diskursseja tutkimalla on mahdollista paljastaa niitä kulttuurisia ja syvään juurtuneita sekä usein piiloisia tapoja ymmärtää työyhteisön toimintakulttuuria ja todellisuutta.

Toinen teoreettinen johtopäätös liittyy toimijuuden käsitteeseen. Käsitteen määrittelyssä sekä myös sen empiirisessä tutkimuksessa on korostunut yksilöiden toimijuuden tarkastelu. Tutkimukseni toi esiin, että toimijuuden käsitteen syvällisemmäksi ymmärtämiseksi tarvitaan toimijuuden tarkastelun kiinnittämistä niin yksilö-, yhteisö- kuin organisaatiotasoihin.

Kysyin puheenvuoroni alussa, onko syytä edes tutkia opettajankoulutusta, kun kaikki näyttäisi olevan niin hyvin. Väitän, että tarve opettajankoulutuksen tutkimukseen on akuutimpaa kuin koskaan aikaisemmin.

Perinteet velvoittavat: Kuten jo vuonna 1882 on ytimekkäästi todettu ja tänne juhlavan Seminariumrakennuksen seinäornamenttiin ikuistettu, "Nuorison parasta tässä harrastetaan". Neljäkymmentä vuotta sit- ten, kun peruskoulua ja yliopistotasoista opettajankoulutusta rakennettiin, harrastettiin myös nuorison parasta, ja näistä oman aikansa kunnianhimoisista ja radikaaleista reformeista me saamme nyt nauttia hyviä oppimistuloksia tuottavan koululaitoksemme myötä koko suomalaisessa yhteiskunnassa.

Mikä on meidän nykyisten toimijoiden vastaus menneiden sukupolvien arvokkaalle työlle? Miten me vastaamme tämän ajan asettamiin haasteisiin? Tämä on kriittinen hetki: Pystymmekö löytämään sellaisia keinoja opettajankoulutuksen uudistamiseksi, jotka takaavat suomalaisen koulujärjestelmän ja opettajankoulutuksen laadun myös seuraavien viiden, kymmenen, neljänkymmenen vuoden päästä yhä kiivaammin muuttuvassa maailmassa.

Opettajankoulutuksen muutosta ei voi sanella Euroopan unioni, poliittinen eliitti, talouselämä tai edes yliopiston hallinto, vaan siitä ovat vastuussa opettajankouluttajat itse. Opettajankouluttajien työn tueksi onkin syytä keskittää voimavaroja ja resursseja opettajankoulutuksen kehittämiseen ja tutkimukseen. Tarvitaan resursseja - tilaa ja aikaa - opettajankouluttajien ammatillisen identiteetin uudistumisen tueksi sekä yhteisöllisen toimijuuden vahvistamiseksi.

Päivi Hökän väitöstutkimuksen Teacher educators amid conflicting demands: tensions between individual and organizational development Lectio Praecursoria 17.2.2012 Jyväskylän yliopistossa. Vastaväittäjänä toimi professori Eero RopoTampereen yliopistosta ja kustoksena professori Helena Rasku-Puttonen Jyväskylän yliopistosta. 